\title{
DIRGLIOSIOS ŽARNOS SINDROMAS. DIAGNOSTIKA IR GYDYMAS
}

\author{
Marius Rinkevičius \\ Lietuvos sveikatos mokslu universitetas, Medicinos akademija, Medicinos fakultetas
}

Raktažodžiai: dirgliosios žarnos sindromas, virškinimas, dirglioji žarna, žarnyno ligos.

\section{Santrauka}

Dirgliosios žarnos sindromas yra dažniausiai diagnozuojama virškinamojo trakto būklè. Tai simptomais pagrịsta būklè, apibūdinama pilvo skausmu ar diskomfortu, kuriuos sukelia pasikeitę ịpročiai. Tyrimo tikslas - remiantis naujausiomis mokslinėmis publikacijomis, apžvelgti dirgliosios žarnos sindromo diagnostiką bei gydymą. Atlikta 24 mokslinių publikacijų apžvalga. Straipsniai atrinkti naudojantis PubMed, UpToDate ir ScienceDirect duomenų bazėmis. I̦ apžvalgą įtrauktos ne senesnès nei dešimties metų publikacijos anglų kalba.

\section{Ivadas}

Dirgliosios žarnos sindromas yra dažniausiai diagnozuojama virškinamojo trakto būklè. Tai simptomais pagrịsta būklè, apibūdinama pilvo skausmu ar diskomfortu, kuriuos sukelia pasikeitę žarnyno ịpročiai. Bendri dirgliosios žarnos sindromo paplitimo įvertinimai skiriasi visame pasaulyje ir yra iš dalies susiję su tyrimo populiacijos skirtumais, diagnostiniais kriterijais ir tyrimo metodika. Šiaurès Amerikoje dirgliosios žarnos sindromo paplitimas apytiksliai yra 12 procentų. Dirgliosios žarnos sindromas labiausiai paplitęs Pietų Amerikoje (21,0\%), o mažiausiai - Pietryčių Azijoje $(7,0 \%)[13,14]$. JAV, Kanadoje ir Izraelyje dirgliosios žarnos sindromo simptomai yra 1,5-2 kartus dažnesni moterims nei vyrams. Azijoje moterys dažniau praneša apie pilvo skausmą ir vidurių užkietejjimą, o vyrai - apie viduriavimą $[13,14]$. Dirgliosios žarnos sindromo paplitimas leidžia numatyti šio sindromo diagnostikos bei gydymo temos nagrinejjimą $[22,23]$.

Tyrimo tikslas - remiantis naujausiomis mokslinėmis publikacijomis, apžvelgti dirgliosios žarnos sindromo diagnostiką bei gydymą.

\section{Tyrimo medžiaga ir metodai}

Atlikta 24 publikacijų mokslinė apžvalga. Straipsniai atrinkti naudojantis PubMed, UpToDate ir ScienceDirect duomenų bazèmis. İ apžvalgą įtrauktos ne senesnès nei dešimties metų publikacijos anglų kalba.

\section{Tyrimo rezultatai}

Dirgliosios žarnos sindromas. Dirgliosios žarnos sindromas (DŽS) yra paplitęs funkcinis virškinamojo trakto sutrikimas, kuriam būdingas lètinis pilvo skausmas ar diskomfortas ir pasikeitę žarnyno ịpročiai [7].

Dirgliosios žarnos sindromu sergančius pacientus kamuoja protarpinis pilvo skausmas (diskomfortas), pakitę žarnyno ịpročiai ir pilvo pūtimas (išsipūtimas) [8, 21]. Pacientai mano, kad jų simptomus sukelia tam tikri maisto produktai, tokie kaip pienas ir pieno produktai, kviečių produktai, kofeinas, kopūstai, svogūnai, žirniai, pupelès, karšti prieskoniai ir keptas bei rūkytas maistas [3,16]. Kai kurie dirgliosios žarnos sindromu sergantys pacientai vengia kai kurių maisto produktų, tačiau neatrodo, kad tarp jų ir visos populiacijos būtų skirtumas dèl energijos, angliavandenių, baltymų ir riebalų $[3,16,22,23]$.

Daugelis pacientų mano, kad jų dirgliosios žarnos sindromo simptomai atsiranda dèl jautrumo maistui. Mechanizmai: maistas sukelia simptomus pacientams, sergantiems dirgliosios žarnos sindromu [17]. Yra keturi galimi paaiškinimai: ryškus kontraktilinis [20] ir sensorinis [19] gaubtinès žarnos atsakas ị maisto nurijimą (skrandžio ir žarnyno atsakas); mikrobiomo pokyčiai (gali ịvykti gana greitai po dietos pakeitimo) [6]; netirpios maistinès skaidulos gali sustiprinti dirgliosios žarnos sindromo simptomus [10]; dietiniai antigenai gali pakeisti žarnyno epitelio barjerą [11]. Šie tariami mechanizmai teikia pagrindą mitybos modifikacijai bei šio sindromo gydymui.

Dirgliosios žarnos sindromo diagnozè gali būti sudètinga dẻl kelių priežasčių: viena, simptomai laikui bėgant gali keistis ir dèl šių svyravimų pacientas gali jaustis taip, tarsi sutrikimas būtų didesnis, nei yra iš tikrujų; antra, dirgliosios žarnos sindromo simptomai gali imituoti kitus sutrikimus (pvz., laktozès ar fruktozès netoleravimas), todèl gali nereaguoti ị empirini gydymą; trečia, gydytojai gali to nežinoti ir netinkamai nustatyti dirgliosios žarnos sindromo diagnozę; be to, nèra dirgliosios žarnos sindromo biologinio 
žymeklio - pacientams galimi nuolatiniai ar pasikartojantys simptomai, bet gydytojai negali užsisakyti testo, kuris patikimai diagnozuotų būklę; galiausiai, pacientai gali norèti atlikti tyrimus nustatyti simptomų priežastis, nors įprastiniai tyrimai paprastai būna normalūs, o tai vargina pacientą, nes simptomai vis tiek išlieka [4].

Dirgliosios žarnos sindromo diagnostika. Klinikinei dirgliosios žarnos sindromo diagnozei dažnai naudojami „Roma IV“ kriterijai, kai jaučiami sindromo požymiai ne mažiau kaip 1 savaitę per pastaruosius 3 mènesius, susiję su dviem ar daugiau iš šių dalykų: 1) su tuštinimusi; 2) išmatų dažnio pasikeitimu ir 3) su išmatų išvaizdos pasikeitimu [24].

Išanalizavus mokslinę literatūrą pastebèta, kad nepaisant dirgliosios žarnos sindromo paplitimo ir dažnai lètinio, pasikartojančio pobūdžio, pagrindinè šio sindromo patofiziologija vis dar nèra visiškai suprantama [1]. Lètinis, žemo laipsnio subklinikinis uždegimas susijęs su ligos procesu. Manoma, kad jis tęsia dirgliosios žarnos sindromo simptomus, neatskleidžiant reikšmingų gaubtinès žarnos gleivinès anomalijų; tačiau, naudojant šiuolaikinius sekos nustatymo metodus, imunohistocheminius tyrimus ir ultrastruktūrines analizes, pastebimi subtilūs mikroskopiniai ir molekuliniai pokyčiai.

Dirgliosios žarnos sindromo gydymas. Dirgliosios žarnos sindromo gydymas turètų apimti paciento susirūpinimą savo sveikata ir tinkamą simptominio gydymo paskyrimą [2].

Tinkamai atlikta konsultacija gali būti terapinè pacientui, sergančiam dirgliosios žarnos sindromu, tačiau tik maža dalis pacientų kreipiasi ị savo šeimos gydytoją, o dar mažesnė dalis kreipiasi ị specialistą [5]. Gydytojai turètų pripažinti, kad pacientams, sergantiems dirgliosios žarnos sindromu, reikalinga holistinè konsultacija. Teigiama diagnozė ir raminantis dirgliosios žarnos sindromo paaiškinimas turètų būti pateikiamas empatiškai, suteikiant pacientui laiko aptarti savo susirūpinimą dèl ligos.

Daugelis pacientų, sergančių dirgliosios žarnos sindromu, praneša apie sunkesnius virškinamojo trakto simptomus, susijusius su tam tikru maistu [9]. Tokiais atvejais puikiai tiktų dieta, kurios metu būtų atsisakyta tam tikro maisto, kuris provokuoja simptomus. Gydytojai turètų priminti pacientui, kad tokiomis dietomis piktnaudžiauti negalima [15] ir kartu su dietologu prižiūrèti paciento mitybos manipuliacijas. Dirgliosios žarnos sindromo simptomus galima sušvelninti reguliariai mankštinantis [12]. Mankštą reikètų rekomenduoti kartu su mitybos patarimais. Taip pat reikètų aptarti miego svarbą, nes nustatyta, kad pagerejjusi miego kokybė kontroliuoja simptomus [18].

Yra daug psichologinių gydymo būdų, kurie pagerina arba pašalina dirgliosios žarnos sindromo simptomus. Tai apima kognityvinę elgesio terapiją, daugiakomponentę psichologinę terapiją ir dinaminę psichoterapiją Kai kurie pacientai pripažista, kad jų simptomai atsiranda stresinèmis aplinkybėmis, arba juos sustiprina stresas ir nerimas. Šiems pacientams psichologinis gydymas yra tiesioginis dirgliosios žarnos sindromo gydymo metodas. Kruopščiai suplanuotas ir suformuluotas kreipimasis ị psichologą, turintį žinių apie funkcinius virškinamojo trakto sutrikimus, pagerina sẻkmingo rezultato tikimybę.

\section{Išvados}

1. Dirgliosios žarnos sindromas yra dažna lètinè virškinamojo trakto liga, kuriai būdingas lètinis pilvo skausmas ar diskomfortas ir pasikeitę žarnyno ịpročiai.

2. Teigiama klinikinè diagnozè nustatoma naudojant Romos kriterijus bei šiuolaikinius sekos nustatymo metodus, imunohistocheminius tyrimus ir ultrastruktūrines analizes, pastebimi subtilūs mikroskopiniai ir molekuliniai pokyčiai.

3. Yra daug gydymo būdų, kurie naudingi pacientams, sergantiems dirgliosios žarnos sindromu, ịskaitant dietą ir psichologiškai pagrįstą terapiją.

\section{Literatūra}

1. Barbara G, Cremon C, de Giorgio R, et al. Mechanisms underlying visceral hypersensitivity in irritable bowel syndrome. Curr Gastroenterol Rep 2011;13(4):308-315. https://doi.org/10.1007/s11894-011-0195-7

2. Basnayke Ch. Treatment of irritable bowel syndrome. 2018.

3. Bohn L, Storsrud S, Tornblom H, Bengtsson U, Simren M. Self-reported food-related gastrointestinal symptoms in IBS are common and associated with more severe symptoms and reduced quality of life. Am J Gastroenterol 2013;108:634-41. https://doi.org/10.1038/ajg.2013.105

4. Brian EL, Nihal KP. Rome Criteria and a Diagnostic Approach to Irritable Bowel Syndrome 2017, 6(11), 99.

https://doi.org/10.3390/jcm6110099

5. Canavan C, West J, Card T. Review article: the economic impact of the irritable bowel syndrome. Aliment Pharmacol Ther 2014;40:1023-34.

https://doi.org/10.1111/apt.12938

6. David LA, Maurice CF, Carmody RN, et al. Diet rapidly and reproducibly alters the human gut microbiome. Nature 2014;505(7484):559-563.

https://doi.org/10.1038/nature12820

7. Drossman DA. Functional Gastrointestinal Disorders: History, Pathophysiology, Clinical Features and Rome IV. Gastroenterology 2016;150(6):1262-1279.

https://doi.org/10.1053/j.gastro.2016.02.032

8. El-Salhy M, Gundersen D, Hatlebakk JG, Hausken T. Irritable bowel syndrome: diagnosis, pathogenesis and treatment op- 
tions. New York: Nova Science Publishers, Inc.; 2012.

https://doi.org/10.2217/cpr.12.41

9. Eswaran SL, Chey WD, Han-Markey T, Ball S, Jackson K. A randomized controlled trial comparing the low FODMAP diet vs. modified NICE guidelines in US adults with IBS-D. Am J Gastroenterol 2016;111:1824-32.

https://doi.org/10.1038/ajg.2016.434

10. Francis CY, Whorwell PJ. Bran and irritable bowel syndrome: time for reappraisal. Lancet 1994;344(8914):39-40. https://doi.org/10.1016/S0140-6736(94)91055-3

11. Fritscher-Ravens A, Schuppan D, Ellrichmann M, et al. Confocal endomicroscopy shows food-associated changes in the intestinal mucosa of patients with irritable bowel syndrome. Gastroenterology 2014;147(5):1012-1020.

https://doi.org/10.1053/j.gastro.2014.07.046

12. Johannesson E, Simrén M, Strid H, Bajor A, Sadik R. Physical activity improves symptoms in irritable bowel syndrome: a randomized controlled trial. Am J Gastroenterol 2011;106:915-22. https://doi.org/10.1038/ajg.2010.480

13. Lovell RM, Ford AC. Global prevalence of and risk factors for irritable bowel syndrome: a meta-analysis. Clin Gastroenterol Hepatol 2012;10 (7):712-721.

https://doi.org/10.1016/j.cgh.2012.02.029

14. Lovell RM, Ford AC. Effect of gender on prevalence of irritable bowel syndrome in the community: systematic review and meta-analysis. Am J Gastroenterol 2012;107(7):991-1000. https://doi.org/10.1038/ajg.2012.131

15. Monsbakken KW, Vandvik PO, Farup PG. Perceived food intolerance in subjects with irritable bowel syndrome-- etiology, prevalence and consequences. Eur J Clin Nutr 2006;60:667-72. https://doi.org/10.1038/sj.ejen.1602367

16. Ostgaard H, Hausken T, Gundersen D, El-Salhy M. Diet and effects of diet management on quality of life and symptoms in patients with irritable bowel syndrome. Mol Med Report 2012;5:1382-90.

17. Ragnarsson G, Bodemar G. Pain is temporally related to eating but not to defaecation in the irritable bowel syndrome (IBS): patients' description of diarrhea, constipation and symptom variation during a prospective 6-week study. Eur J Gastroenterol Hepatol 1998;10(5):415-421.

https://doi.org/10.1097/00042737-199805000-00011

18. Siah KT, Wong RK, Ho KY. Melatonin for the treatment of irritable bowel syndrome. World J Gastroenterol 2014;20:2492-8. https://doi.org/10.3748/wjg.v20.i10.2492
19. Simrén M, Abrahamsson H, Björnsson ES. An exaggerated sensory component of the gastrocolonic response in patients with irritable bowel syndrome. Gut 2001;48(1):20-27. https://doi.org/10.1136/gut.48.1.20

20. Sullivan MA, Cohen S, Snape WJ Jr. Colonic myoelectrical activity in irritable-bowel syndrome: effect of eating and anticholinergics. N Engl J Med 1978;298(16):878-883.

https://doi.org/10.1056/NEJM197804202981604

21. Thompson WG. A World View of IBS. In: Camilleri M, Spiller RC, editors. Irritable Bowel Syndrome. Philadelphia and London: Saunders, 2002.

22. Chey WD, Kurlander J, Eswaran S. Irritable Bowel Syndrome: a clinical review. JAMA 2015;313(9):949-58.

https://doi.org/10.1001/jama.2015.0954

23. Williams EA, Nai X, Corfe BM. Dietary intakes in people with irritable bowel syndrome. BMC Gastroenterol 2011;11:9. https://doi.org/10.1186/1471-230X-11-9

24. Ng QX, Soh AYS, Loke W, Lim DY, Yeo WS. The role of inflammation in irritable bowel syndrome (IBS). J Inflamm Res 2018;11:345-349.

https://doi.org/10.2147/JIR.S174982

\section{IRRITABLE BOWEL SYNDROME. DIAGNOSIS AND TREATMENT}

\section{Rinkevičius}

Keywords: irritable bowel syndrome, digestion, irritable bowel, intestinal diseases.

Summary

Irritable bowel syndrome is the most commonly diagnosed condition of the gastrointestinal tract. it is a symptomatic condition characterized by abdominal pain or discomfort caused by altered bowel habits that cause such symptoms despite other diseases. the prevalence of irritable bowel syndrome makes it possible to predict a proper examination of the topic of diagnosis and treatment of this syndrome. the aim of the study is to review the diagnosis and treatment of irritable bowel syndrome based on the latest scientific publications. a scientific review of 24 publications was performed. articles were selected using pubmed, uptodate, and sciencedirect databases. the review includes publications in english not older than ten years.

Correspondence to: mariusdvynys@gmail.com

Gauta 2021-09-06 